\title{
Viable phototrophic sulfur bacteria from the Black-Sea bottom
}

\author{
F. A. Hashwa* \& H. G. TRÜPER \\ Institut für Mikrobiologie der Universität Bonn; \\ Meckenheimer Allee 168, D-5300 Bonn, Federal Republic of Germany
}

\begin{abstract}
Phototrophic sulfur bacteria were isolated from Black-Sea mud at depths of 660 and $2,240 \mathrm{~m}$. The species obtained in pure cultures were identified as Chromatium warmingii and Thiocapsa roseopersicina. In addition, Chlorobium phaeovibrioides occurred in enrichment cultures. The findings prove that Chromatiaceae and Chlorobiaceae are capable of survival in $2000 \mathrm{~m}$ depth, in the dark, in the presence of $\mathrm{H}_{2} \mathrm{~S}$ and organic materials. There is, however, no evidence for growth or reproduction of these organisms in this environment.
\end{abstract}

\section{INT'RODUCTION}

In 1953, Kriss \& Rukina reported enrichments of phototrophic sulfur bacteria from anoxic deep waters far below the photic zone of the Black Sea. Their positive samples had been taken from depths between 500 and $2,000 \mathrm{~m}$. Kriss' \& Rukina's theory that these organisms might grow in the dark deep waters at the expense of radioactive radiation rather than of light has been disproven by Kuznetsov (1956). Therefore the findings of Kriss and Rukina remained doubtful in the eyes of many microbial physiologists working with phototrophic sulfur bacteria, especially, because the above cited authors did not report the subsequent isolation and identification of pure cultures.

During 1969, at $\mathrm{R} / \mathrm{V}$ “Atlantis II" cruise no. 49, Trüper tried to isolate phototrophic sulfur and nonsulfur bacteria from 84 different water samples taken at different stations (no. 1461-1484) and depths between 30 and 2,175 m (cf. Jannasch et al., 1974). While Kriss \& Rukina used simple media, Trüper applied the modern media devised by Pfennig (1965; Trüper, 1970) and concentrated water samples of 250 til $1,400 \mathrm{ml}$ by membrane filtration, inoculating the liquid media with the membrane filters. All efforts remained without success, which lead to the conclusion that Kriss \& Rukina (1953) must have been mistaken.

In 1975, during $\mathrm{R} / \mathrm{V}$ "Chain" cruise no. $120 / 1$ we have again tried to isolate phototrophic bacteria from Black Sea deep waters and upper sediment layers using a new variety of media. The results are reported in this paper.

* Present address: Biology Department, University of Amman; Amman, Jordan 


\section{MATERIAL AND METHODS}

The following media were used for enrichments: (I) medium for thiosulfatereducing bacteria (Tuttle \& Jannasch, 1973); (II) medium for phototrophic sulfur bacteria (Pfennig, 1965) with $3 \%$ salt (Trüper, 1970), pH 7.0; (III) same, pH 8.0; (IV) medium for Rhodospirillaceae (Hashwa, 1972); (V) medium for Rhodospirillaceae (Hansen, 1974) with $0.05 \%$ sulfide.

The media were sterilized by filtration and distributed into sterile $50 \mathrm{ml}$ screw cap bottles. Water samples were taken with sterile Niskin samplers (Niskin, 1962). $250 \mathrm{ml}$ of each water sample were filtered through sterile membrane filters (pore size $0.45 \mu \mathrm{m}$ ), the filters then cut aseptically into 5 equally sized pieces which served as inocula for the bottle cultures. In addition, several sediment samples were collected aseptically from sediment cores (black, upper 1-2 cm layers) and also used as inocula.

Sampling sites: Station No. 1354, depth $660 \mathrm{~m}$ (north of Bosporus), 8 water samples between 50 and $400 \mathrm{~m}$; Station No. 1355, depth $2240 \mathrm{~m}$ (western central basin), 29 water samples between 10 and $600 \mathrm{~m}$; Station No. 1356, depth $2100 \mathrm{~m}$ (western central basin), 8 water samples between 81 and $600 \mathrm{~m}$.

Altogether 225 enrichment cultures were inoculated with pieces of membrane filters and 20 cultures with mud samples. The cultures were incubated at $8^{\circ} \mathrm{C}$ and the low light intensity of a $30 \mathrm{~W}$ incandescent light bulb for 8-10 weeks.

\section{RESULTS}

None of the water samples were positive with respect to the development of pigmented phototrophic bacteria although numerous other bacteria (probably heterotrophic thiosulfate-reducers; Tuttle \& Jannasch, 1973) were observed. This result was expected, since it confirmed our previous findings (Jannasch et al., 1974).

To our great surprise, however, the following enrichment cultures inoculated with mud showed positive developments of phototrophic bacteria: (a) Mud no. 1354 (depth $660 \mathrm{~m}$ ), medium III; (b) Mud no. 1355 (depth 2,240 m), medium I; (c) Mud no 1355, medium I; (d) Mud no. 1356 (depth 2,100 m), medium II; (e) Mud no. 1356, medium II.

Culture a first showed a green-brownish sediment (rods, $1 \mu \mathrm{m}$ diameter, occuring in chains) which later turned purple red when a large cell Chromatium species started to dominate. The strain - after purification by repeated agar shake series (Pfennig, 1965) - was identified as Chromatium warmingii. Like the type strain it does not utilize thiosulfate, is unable of assimilatory sulfate reduction, and contains hydrogenase (Pfennig \& Trüper, 1974). The strain has been included into our current research on sulfur metabolism and proved to contain rhodanese as well as thiosulfate reductase (Hashwa, unpublished). The strain is not obligately salt requiring.

Cultures $b$ and $c$ showed a slow development of pink patches below the mud sediment in the enrichment. In the microscope small (diameter 1-2 $\mu \mathrm{m}$ ) coccoid cells dominated that contained sulfur globules. The cells often occurred in pairs. After purification, the culture was identified by the criteria of Pfennig \& Trüper (1974) as Thiocapsa roseopersicina. 
The strain utilizes thiosulfate and is capable of assimilatory sulfate reduction in heterotrophic media; it is not obligately salt requiring.

Cultures d-e showed brown sediments which by microscopic examination appeared to consist of brown chlorobia, probably Chlorobium phaeobacteroides. Because the growth rate obviously was extremely low we did not try to achieve pure cultures in these cases.

\section{DISCUSSION}

The phototrophic nature of Chromatium warmingii and Thiocapsa roseopersicina demands sufficient light for their normal development. Therefore it seems unlikely that these bacteria are able to proliferate at the Black-Sea bottom where definitely no light is available. In addition, the high $\mathrm{H}_{2} \mathrm{~S}$ content of the water below the chemocline does not allow aerobic dark respiratory metabolism, as it is well known for some of the Rhodospirillaceae and as it has been reported for $T$. roseopersicina too (Pfennig $\&$ Trüper, 1974).

Thus there remains only one possibility to meet the energy requirement of survival: fermentation. While the anaerobic dark metabolism of the phototrophic nonsulfur bacteria has been well studied in several research laboratories (e. g. Uffen $\& x$ Wolfe, 1970; Schön, 1968; Gürgün et al., 1976), relatively little is known of the anaerobic dark metabolism of phototrophic sulfur bacteria. Hendley (1955) was the first - basing on pilot studies of van Niel (1936) to study "endogenous fermentation" in Chromatiaceae. Photoautotrophically grown cells of Chromatium vinosum were found to produce $\mathrm{H}_{2} \mathrm{~S}, \mathrm{CO}_{2}$ and acetate under dark/anaerobic conditions. This was confirmed by Trüper \& Schlegel (1964) for the large cell species Chromatium okenii. Van Gemerden (1968) studied the stoichiometry of dark/anaerobic metabolism of Chromatium vinosum and found that under these conditions storage polysaccharides are transformed into storage poly- $\beta$-hydroxybutyrate, while ATP is generated during glycolysis and hydrogen is transferred upon elemental storage sulfur and excreted as $\mathrm{H}_{2} \mathrm{~S}$.

All of these results, however, demand that the cells had a period of active storage of sulfur and polysaccharides before, i. e., an active period of anaerobic photosynthesis. It is rather unlikely that the strains isolated from the Black-Sea bottom close to the center of the western basin had such a period recently before their isolation.

Krasilnikova et al. (1975) were the first to report "growth" of purple sulfur bacteria under dark/anaerobic conditions: they were able to grow Thiocapsa roseopersicina in media containing glucose and thiosulfate or elemental sulfur. Also Chromatium minutissimum and Ectothiorbodospira shaposhnikovii were found to grow under dark/anaerobic conditions (Krasilnikova et al., 1976). In addition to glucose or fructose these species utilized organic acids (malate, succinate, lactate, pyruvate, butyrate, acetate) under these conditions.

These results render it likely that our strains from the Black-Sea bottom survived there by a fermentative metabolism - most probably at the expense of organic acids. High amounts of organic carbon have been frequently reported in Black-Sea sediments (cf. Degens \& Ross, 1977). 
The environmental conditions at the Black Sea bottom thus may allow survival but active proliferation of these bacteria still appears unlikely, because metabolic turnover rates are - as clearly demonstrated by Jannasch et al. (1971, 1976) - extremely low at deep sea hydrostatic pressures.

Our samples were collected north of the Bosporus in the western central basin of the Black Sea. Certainly this is not the natural environment of phototrophic bacteria. It has to be assumed, therefore, that these bacteria have been washed away from their estuarine "home" environments and as such the northern shores of the Black Sea with their numerous coastal lagoons ("limans") are the most probable places of their origin. This is emphasized by their lack in an obligate salinity requirement.

Although we do not know the exact taxonomic position of the organisms described by Kriss \& Rukina (1953) as phototrophic bacteria, we have confirmed their findings that such bacteria do occur in the depth of the Black Sea.

Acknowledgements. We wish to thank Dr. H. W. Jannasch and the Woods Hole Oceanographic Institution for the invitation to participate in "Chain" Cruise No. 120/1. Our participation was facilitated by a travel grant of the Deutsche Forschungsgemeinschaft.

\section{LITERATURE CITED}

Degens, E. T. \& Ross, D. A., (Eds.), 1974. The Black Sea - Geology, chemistry, and biology. Am. Ass. Petrol Geologists, Tulsa, Oklahoma (Memoir. 20.), 633 pp.

Gürgün, V., Kirchner, G. \& Pfennig, N., 1976. Fermentation of pyruvate by seven species of phototrophic purple bacteria. Z. allg. Mikrobiol. 16, 573-586.

Hansen, T. A., 1974. Sulfide as electrondonor voor Rhodospirillaceae. Diss., Univ. Groningen, $68 \mathrm{pp}$.

Hashwa, F., 1972. Die enzymatische Thiosulfatspaltung bei phototrophen Bakterien. Diss. Univ. Göttingen, $145 \mathrm{pp}$.

Hendley, D. D., 1955. Endogenous fermentation in Thiorhodaceae. J. Bact. 70, 625-634.

Jannasch, H. W., Eimhjellen, K., Wirsen, C. O. \& Farmanfamaian, A., 1971. Microbial degradation of organic matter in the deep sea. Science, N.Y. 171, 672-675.

- Trüper, H. G. \& Tuttle, J. H., 1974. Microbial sulfur cycle in Black Sea. In: The Black Sea - Geology, Chemistry, and Biology. Ed. by E. T. Degens \& D. A. Ross. Am. Ass. Petroleum Geologists, Tulsa, Oklahoma, 419-425. (Memoir. 20.)

- Wirsen, C. O. \& Taylor, C. D., 1976. Undecompressed microbial populations from the deep sea. Appl. environ. Microbiol. 32, 360-367.

Krasilnikova, E. N., Pedan, L. V. \& Kondratieva, E. N., 1976. Growth of purple sulfur bacteria in dark under anaerobic conditions. Mikrobiologiya 45, 581-585.

- Petushkova, Yu. P. \& Kondratieva, E. N., 1975. Growth of the purple sulfur bacterium Thiocapsa roseopersicina under anaerobic conditions in the darkness. Mikrobiologiya 44, $700-703$.

Kriss, A. E. \& Rukina, E. A., 1953. Purple sulfur bacteria in deep sulfurous water of the Black Sea. Dokl. Akad. Nauk. SSSR 93, 1107-1110.

Kuznetsov, S. I., 1956. On the possibility of radiosynthesis. Mikrobiologiya 25, 195-199.

Niskin, S. J., 1962. A water sampler for microbiological studies. Deep Sea Res. 9, 501-503.

Pfennig, N., 1965. Anreicherungskulturen für rote und grüne Schwefelbakterien. Zbl. Bakt. ParasitKde (Abt. 1.) Suppl. 1, 179-189, 503-504.

- \& Trüper, H. G., 1974. The phototrophic bacteria. In: Bergey's Manual of Determinative Bacteriology. Ed. by R. E. Buchanan \& N. E. Gibbons. Williams \& Wilkins, Baltimore, 24-64. 
Schön, G., 1968. Fructoseverwertung und Bacteriochlorophyllsynthese in anaeroben Dunkelund Lichtkulturen von Rbodospirillum rubrum. Arch. Mikrobiol. 63, 362-375.

Trüper, H. G., 1970. Culture and isolation of phototrophic sulfur bacteria from the marine environment. Helgoländer wiss. Meeresunters. 20, 6-16.

- \& Schlegel, H. G., 1964. Sulphur metabolism in Thiorhodaceae. I. Quantitative measurements on growing cells of Chromatium okenii. Antonie van Leeuwenhoek 30, 225-238.

Tuttle, J. H. \& Jannasch, H. W., 1973. Dissimilatory reduction of inorganic sulfur by facultatively anaerobic marine bacteria. J. Bact. 115, 732-737.

Uffen, R. L. \& Wolfe, R. S., 1970. Anaerobic growth of purple non-sulfur bacteria under darkconditions. J. Bact. 104, 462-472.

Van Gemerden, 1968. On the ATP generation by Cbromatium in darkness. Arch. Mikrobiol. 64, 118-124.

Van Niel, C. B., 1936. On the metabolism of the Thiorhodaceae. Arch. Mikrobiol. 7, 323-358. 